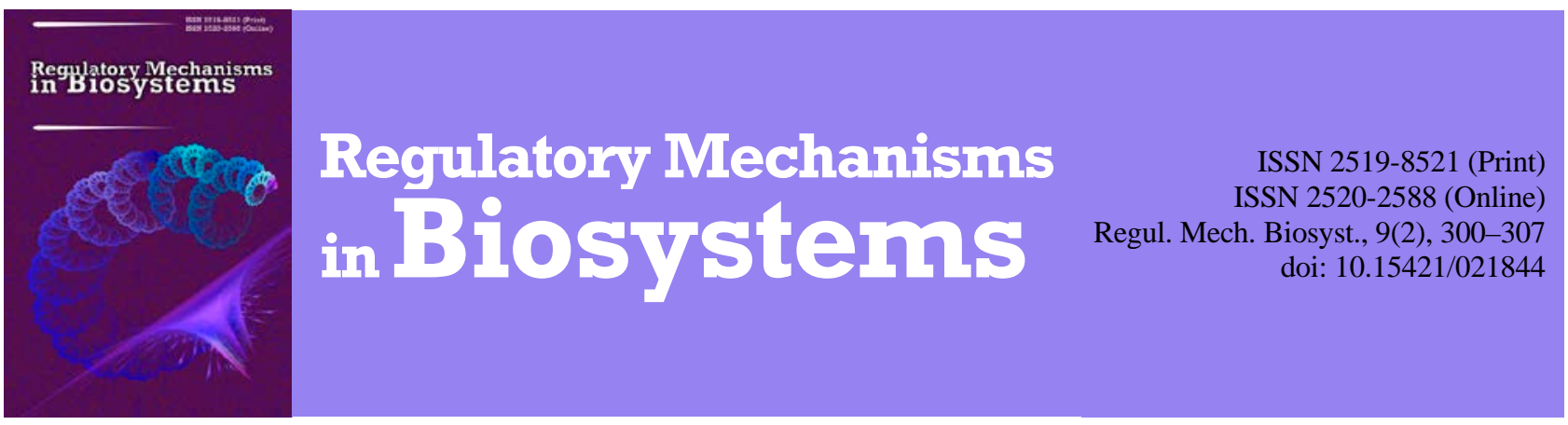

\title{
Cytoprotective processes induced by the effect of L-arginin-L-glutamate in rats with experimental pathology of the gastroduodenal zone
}

\author{
Y. M. Stepanov*, L. A. Ponomarenko**, O. A. Lykholat***, \\ T. M. Shevchenko****, O. M. Khomenko****, A. A. Ponomarenko***** \\ *Institute of Gastroenterology of the National Academy of Medical Sciences of Ukraine, Dnipro, Ukraine \\ **Dnipropetrovsk Regional Children's Clinical Hospital, Dnipro, Ukraine \\ ***University University of Customs Business and Finance, Dnipro, Ukraine \\ ****Oles Honchar Dnipro National University, Dnipro, Ukraine \\ *****Kam'yanke' City Hospital No 9, Kam'yanke, Ukraine
}

Article info

Received 25.03.2018

Received in revised form 30.04.2018

Accepted 01.05.2018

Institute of Gastroenterology of the National Academy of Medical Sciences of Ukraine,

Slobozhansky Ave., 96,

Dnipro, 49000, Ukraine.

Tel.: +38-050-056-78-42

E-mail: gastrodnepr@gmail.com

Oles Honchar Dnipro National University, Gagarin Ave., 72,

Dnipro, 49010, Ukraine.

Tel.: +38-056-372-58-76

E-mail:

dnushevchenkot@gmail.com

Dnipropetrovsk Regional Children's Clinical Hospital,

Kosmicheskaja st., 13,

Dnipro, 49100, Ukraine.

Tel.: +38-056-713-71-00

E-mail: kdl17lud@gmail.com

University of Customs and

Finance, V. Vernadsky st., 2/4,

Dnipro, 49000, Ukraine.

Tel.: +38-066-038-68-92

E-mail: Lykholat2010@ukr.net

Kam'yanke' City Hospital No 9 Anoshkin st., 72,

Kam'yanke, 51900, Ukraine.

Tel.: +38-056-776-56-66

E-mail: oncoll@i.ua
Stepanov, Y. M., \& Ponomarenko, L. A., Lykholat, O. A., Shevchenko, T. M., Khomenko, O. M., \& Ponomarenko, A. A. (2018). Cytoprotective processes induced by the effect of L-arginin-L-glutamate in rats with experimental pathology of the gastroduodenal zone. Regulatory Mechanisms in Biosystems, 9(2), 300-307. doi:10.15421/021844

The processes of effect of L-arginine-L-glutamate on peroxidation and slime-forming function of the stomach cells, the system of antioxidant defense in the blood, liver and brain tissues of rats with experimental pathology of the gastroduodenal zone have been investigated. The animals were divided into four groups. Group I - control group were rats injected intragastrically through a probe physiological solution. Group II included animals with erosive ulcerative lesions of the gastroduodenal zone. Modeling of the erosive ulcerative lesions was carried out by intragastric administration of medical bile $(1 \mathrm{ml} / 100 \mathrm{~g})$ in combination with immobilization-cold stress for 1 hour at $+4{ }^{\circ} \mathrm{C}$ for a period of seven days. Rats of group III simultaneously received an intra-abdominal 4\% solution of L-arginine-L-glutamate in a dose of $20 \mathrm{mg}$ per $100 \mathrm{~g}$ of body weight at the same time as the erosive ulcerative lesions modeling. To clarify the role of NO-ergic mechanism of L-arginine-Lglutamate influence on the quantitative composition of mucins and free radical processes rats in group IV with erosive ulcerative lesions were injected with non-selective NO-synthase inhibitor, L-NAME (L-NG-nitroarginine methyl ester), at a dose of $1 \mathrm{mg}$ per $100 \mathrm{~g}$ at the same time as injections of $4 \%$ solution of L-arginine-L-glutamate. The simulation of erosiveulcerative lesions of the gastroduodenal zone in the experimental animals was accompanied by the intensification of lipid peroxidation processes, the imbalance of the antioxidant defense systems and the development of oxidative stress in the blood, tissues of the stomach, liver and brain, which has tissue-specific features. In the blood of the animals, the activation of the enzymatic link of antioxidant defense did not compensate for free radical processes, as a result, the exhaustion of the reduced glutathione pool occurred, and the level of TBA-active products increased both in plasma and in erythrocytes. There was a depression of the enzymes of the antioxidant defense and a decrease in the level of recovered glutathione, indicating decompensating of the liver antioxidant protection systems in the liver tissue of the rats. In the experimental animals , formation of erosive ulcerative lesions was accompanied by destabilization of the oxidation-reducing processes in the brain, which led to the intensification of the lipoperoxidation. In the mucous membrane of the stomach of the experimental animals, the total number of protection factors - secretory mucins with a simultaneous structural change - decreased. The use of L-arginine-Lglutamate reduced the manifestations of oxidative stress in the stomach tissue of animals with experimental pathology and normalized the quantitative and qualitative composition of mucins. In the blood, liver tissues and brain of the rats, L-arginine-Lglutamate injections activated the enzymes of the first anti-radical linkage - superoxide dismutase and catalase contributed to the increase of the pool of reduced glutathione and the deceleration of free radical reactions. Investigation of reactions to the action of the inhibitor provides the basis for the hypothesis of the NO-mediated action of L-arginine-L-glutamate on the formation of S-nitrosothiols, as evidenced by the high level of reduced glutathione when the inhibitor is used.

Keywords: erosive and ulcerative pathology; mucosal protection factors; antioxidant system; nitric oxide

\section{Цитозахисні процеси, індуковані впливом L-аргініну-L-глутамату, у щурів з експериментальною патологією гастродуоденальної зони}

\author{
Ю. М. Степанов*, Л. А. Пономаренко**, О. А. Лихолат***, \\ Т. М. Шевченко****, О. М. Хоменко****, О. А. Пономаренко*****
}


*Державна установа «Інститут гастроентерології НАМН України», Дніпро, Україна

**Комунальний заклад «Дніпропетровська обласна дитяча клінічна лікарня ДОР», Дніпро, Україна

***Університет митної справи та фінансів, Дніпро, Україна

****Дніпровський начіональний університет імені Олеся Гончара, Дніпро, Украӥна

*****ККомунальний заклад «Кам’янська міська лікарня № 9 ДОР», Кам’янське, Украйна

Досліджували механізми впливу L-аргініну-L-глутамату на пероксидацію та слизотвірну функцію клітин шлунка, систему антиоксидантного захисту у крові, тканинах печінки та мозку щурів з експериментальною патологією гастродуоденальної зони. Тварин розділили на чотири групи. Група I - контрольна, якій уводили внутрішньошлунковим шляхом через зонд фізіологічний розчин. Група II включала тварин 3 ерозивновиразковими ураженнями гастродуоденальної зони. Моделювання патології проводили шляхом внутрішньошлункового введення медичної жовчі (1 мл/100 г) у поєднанні з іммобілізаційним холодовим стресом протягом однієї години за температури $+4{ }^{\circ} \mathrm{C}$ упродовж сьоми діб. Щури групи III одержували внутрішньочеревні ін’єкції 4\% розчин L-аргініну-L-глутамату у дозі 20 мг/100 г маси тіла одночасно 3 моделюванням ерозивновиразкового ураження. Для уточнення ролі NO-ергічного механізму впливу L-аргініну-L-глутамату на кількісний склад муцинів та вільнорадикальні процеси щурам групи IV з ерозивно-виразковим ураженням уводили неселективний інгібітор NO-синтази L-NAME (L-NGNitroarginine methyl ester) у дозі 1 мг/100 г одночасно з ін'єкціями 4\% розчину L-аргініну-L-глутамату. Моделювання цієї патології в експериментальних тварин супроводжується інтенсифікацією процесів перекисного окиснення ліпідів, дисбалансом антиоксидантних систем захисту та розвитком окисного стресу в крові, тканинах шлунку, печінки, мозку, що має специфічні тканині властивості. У крові тварин активація ферментативної ланки антиоксидантної системи не компенсувала вільнорадикальні процеси, внаслідок чого відбувалося вичерпання пулу відновленого глутатіону, а рівень ТБК-активних продуктів збільшувався як у плазмі, так і в еритроцитах. Депресія ферментів антиоксидантного захисту та зниження рівня відновленого глутатіону свідчили про декомпенсацію печінкових антиоксидантних захисних механізмів у щурів. Формування ерозивно-виразкового ураження гастродуоденальної зони супроводжувалося дестабілізацією окисно-відновних процесів у мозку, що спричиняло інтенсифікацію ліпопероксидації. У слизовій оболонці шлунка експериментальних тварин зменшується загальна кількість факторів захисту - секреторних муцинів. Використання L-аргініну-L-глутамату зменшує прояви окисного стресу у тканині шлунка тварин 3 експериментальною патологією, нормалізує кількісний та якісний склад муцинів. У крові, тканинах печінки, мозку щурів, iн'єкції L-аргініну-Lглутамату активізують ферменти першої антирадикальної ланки (супероксиддисмутаза та каталаза), сприяють збільшенню пулу відновленого глутатіону та уповільненню вільнорадикальних реакцій. Дослідження реакцій на дію інгібітору дає підставу для гіпотези NO-опосередкованої дії L-аргініну-L-глутамату з утворенням S-нітрозотіолів, про що свідчить високий рівень зниженого глутатіону за даних умов.

Ключові слова: ерозивно-виразкова патологія; фактори захисту слизової оболонки; антиоксидантна система; оксид азоту

\section{Вступ}

Структурні та функціональні ураження слизової оболонки (СО) верхніх відділів гастродуоденальної зони відбуваються під час порушення рівноваги між багатокомпонентною системою захисту СО та агресивними ендогенними та екзогенними патогенетичними чинниками. Авангардом захисту СО шлунка та дванадцятипалої кишки виступає слизово-бікарбонатний буфер, утворений товстою плівкою слизового гелю на поверхні покривного епітелію. Шар слизу захищає клітини від протеолізу та пошкодження іонами водню (Barinov et al., 2013; Hlynov \& Chikunova, 2016). Ocновний компонент слизового гелю, що визначає його фізико-хімічні властивості, - муцин. Молекула муцину складається 3 центрально розташованої поліпептидної ланки - апомуцину, що має специфічну область тандемних повторів, у складі яких превалюють пролін, треонін і серин, та прикріплених до них О-глікозідним зв'язком олігосахаридів. Саме склад олігосахаридних структур визначає характерні риси та функціональні особливості муцинів. Він специфічний для різних клітин і тканин. Нині ідентифіковано склад понад 20 муцинів (MUC) і генів, що їх кодують. До секреторних муцинів, здатних утворювати гель, що експресуються в гастроінтестинальному тракті, належать MUC2, MUC5AC, MUC5B, MUC6 (Zolotova, 2014). Основні муцини шлунка - MUC5AC, MUC5B, MUC6. Вони мають у складі термінальні епітопи в основному 3 нейтральними гліканами, тоді як у MUC2, що експресується келихоподібними клітинами кишечнику, периферійні ланцюги значно сіалізовані (Larsson et al., 2013).

Структурна цілісність СО залежить від координованої дії багатьох фізіологічних факторів та мікроциркуляторної ланки, що підтримує необхідний мікроклімат для клітинного відновлення. Безперервний мікросудинний кровотік забезпечує доставку кисню та поживних речовин у СО. Ендотеліальні клітини капілярів генерують захисні медіатори - регулятори інтенсивності кровотоку (Yandrapu \& Sarosiek, 2015). Основний медіатор, який опосередковує судинорозширювальні ефекти ендотелійзалежних вазодилататорів, - оксид азоту (NO). Це вільнорадикальна молекула, що продукується in vivo у регульованому ферментативному процесі з Lаргініну за допомогою родини NO-синтаз (NOS). NO модулює широкий спектр сигнальних шляхів практично в усіх органах і системах організму, включаючи вазоділатацію, нейрональну трансмісію, імуномодуляцію, сердцеве скорочення, інгібування агрега- ції тромбоцитів, диференціювання та проліферацію стовбурових клітин (Lei, 2013; Cossenza \& Socodato, 2014; Kumar, 2017). У гастродуоденальній зоні NO стимулює секрецію слизу за допомогою активації гуанілатциклази в епітеліальних клітинах (Lundberg \& Weitzberg, 2012; Tkach et al., 2013). У відповідь на зворотню дифузію $\mathrm{H}^{+}$-іонів $\mathrm{NO}$ опосередковано (через генерацію простагландинів) впливає на посилення бікарбонатної секреції (Wallace et al., 2017). Беззаперечна роль NO у відновленні мікроциркуляції у CO гастродуоденальної зони, що має вирішальне значення для іï захисту. Ендотеліальні клітини капілярів здатні відчувати зміни кров'яного тиску, рівень кисню у крові, гіпоксію. Нестимульований судинний ендотелій зазвичай діє як вибірковий бар'єр між просвітом судин і навколишніми тканинами, регулює обмін поживних речовин і метаболітів, запобігаючи при цьому потраплянню патогенів або шкідливих речовин у тканини (Kirichuk et al., 2008). У відповідь на локальні стимули ендотеліальні клітини СО гастродуоденальної зони продукують низку захисних ендотеліальних медіаторів, дія яких опосередкована через біосинтез NO, простацикліну, простагландину, активатора плазміногену, судино-епітеліального фактору росту. У результаті синтезу цих речовин у судинному ендотелії зменшується активація лейкоцитів і тромбоцитів, відбувається стимулювання тромболізису, запобігання утворенню тромбів, підтримується перфузія тканин і захист мікросудин від ураження (Tarnawski et al., 2012).

Розпізнавання шкідливих чинників відбувається завдяки аферентним сенсорним нейронам і нервам, що утворюють щільне сплетіння в основі СО та іннервують підслизові судини. Останніми десятиліттями отримано нові дані щодо ролі у забезпеченні цілісності СО гастродуоденальної зони центральної нервової системи. Досліджено механізми комунікації між центральною та ентеральною нервовою системою, що відбуваються через аферентні чутливі волокна вагуса, які передають інформацію про зміну структурного та функціонального гомеостазу шлунково-кишкового тракту у відповідні центральні структури. Оброблення отриманих сигналів супроводжується передачею імпульсів по еферентним волокнам вагуса та адренергічним волокнам симпатичних нервів до периферії та модулюється нейрогуморальною секрецією гастроінтестинальних гормонів і пептидів (Sulaeva, 2015). На локальному рівні роль кінцевих ефекторів захисту СО шлунка та дванадцятипалої кишки належить NO, простагландинам і кальцитонін-ген-зв'язаному пептиду (Taché, 2012; Gyires et al., 2015; 
Sgambato et al., 2016). Одночасна генерація таких локальних посередників, як NO та простагландини, наводить дослідників на думку про множинні рівні взаємодії між шляхами синтезу цих речовин (Zolotarev et al., 2017). Вивчаються механізми, через які може відбуватись взаємне регулювання активності ензимів синтезу простагландинів - циклооксигеназ і NOS. Інгібування циклооксигеназ аспірином та індометацином значно послаблювало активність NOS, a їх активація, у свою чергу, модулює шлях L-аргінін-NO. Але взаємодія між NO та простагландинами не односпрямована, що пов'язане з радикальною природою NO та мікрооточенням. За окисного стресу та ішемії спостерігається інгібування циклооксигеназ, арахідонова кислота метаболізується ліпоксигеназним шляхом 3 утворенням лейкотрієнів, що посилюють запалення. Припускають, що підвищене продукування пероксинітриту спричиняе нітрування залишків тирозину в циклооксигеназах із генерацією нітротирозинів, внаслідок чого відбувається інактивація ензиму. У той же час існує думка, що пероксинітрит може виступати і як активатор циклооксигеназ унаслідок взаємодії із залізом у їх гемовій групі з утворенням проміжного радикального продукту, що впливає на каталітичний процес (Kim, 2014).

Реакції за участю вільнорадикальних молекул - складові нормального метаболізму біологічних систем. Фізіологічні рівні кисневих і азотних інтермедіатів виконують різні важливі функції, серед яких антимікробні, сигнальні, антиапоптичні (Lykholat et al., 2016a; Pérez et al., 2017). Надмірна генерація активних форм кисню (АФК), для якої недостатня природна захисна антиоксидантна буферна ємність, викликає окисне пошкодження тканин. Гастроінтестинальний тракт - ключове джерело АФК, оскільки постійно контактує 3 кишковою мікрофлорою, дієтичними факторами та має найвищу концентрацію ксантиноксидази в організмі, що разом із фагоцитарними клітинами генерують значну кількість супероксид аніонів (Bhattacharyya et al., 2014). За відсутності патологічного процесу в СО гастродуоденальної зони відмічається збалансована активність ферментативних систем, що генерують АФК, i систем антиоксидантного захисту (АОЗ). Порушення балансу між утворенням АФК та їх утилізацією, що викликають надмірне накопичення продуктів перекисного окиснення ліпідів (ПОЛ), характеризується як окисний стрес (Lykholat et al., 2016b; Yermishev et al., 2017). Дія факторів агресії у СО супроводжується пошкодженням іiі клітинних структур (насамперед, мітохондрій), що викликає порушення мітохондріального трансмембранного потенціалу та виток мітохондріального супероксиду. Це, у свою чергу, індукує розвиток окисного стресу та апоптоз клітин СО (Matsui et al., 2011; Kwiecien et al., 2014).

Існує значна кількість досліджень щодо захисного впливу амінокислот під час ураження СО гастродуоденальної зони. У статті (Kunio et al., 2013) показано, що дієтичний глутамат здатний активувати шлункові аферентні вагусні волокна 3 наступною продукцією NO та стимуляцією синтезу муцинів. Застосування глутамату натрію у тварин з індометацин-індукованим ураженням СО супроводжувалось посиленням експресії фактору росту судинного ендотелію та ангіогенезом (Amagase et al., 2015). Амінокислота L-аргінін реалізує свої захисні властивості в СО гастродуоденальній зоні через антиоксидантні механізми та NO-систему (Jiménez et al., 2004; El-Demerdash et al., 2010). Фармакологічний препарат L-аргінін-L-глутамату, відомий своєю гіпоаммоніємічною, гепатопротекторною дією (Babak et al., 2005), досліджується як донатор NO за патології серцево-судиної системи (Semenchuk et al., 2017), в експериментальних моделях - як прокінетик під час лікування симптомів функціональної диспепсії (Ishibashi-Shiraish et al., 2016).

Мета статті - встановити вплив L-аргінін-L-глутамату на процеси пероксидації та слизотвірну функцію клітин шлунка, систему антиоксидантного захисту в крові та тканинах печінки та головного мозку щурів з експериментальною патологією гастродуоденальної зони.

\section{Матеріал і методи досліджень}

Дослідження проводили на білих безпородних щурах-самцях масою 220-250 г (n=24). Дослідження проводили згідно з вимога- ми Європейської комісії нагляду за проведенням лабораторних та інших досліджень за участю експериментальних тварин. Методика проаналізована та схвалена локальним комітетом із біоетики Державної установи «Інститут гастроентерології НАМН України». Тварин розподілили на чотири групи. Група I - контрольна (n = 6); щурам внутрішньошлунково (через зонд) уводили фізіологічний розчин. До групи II ( $\mathrm{n}=6)$ увійшли тварини з ерозивно-виразковими ураженнями (ЕВУ) гастродуоденальної зони. Моделювання EВУ здійснювали за схемою, наведеною Tarasenko et al. (2001), шляхом інтрагастрального уведення медичної жовчі (1 мл/100 г) в поєднанні 3 імобілізаційно-холодовим стресуванням протягом однієї години за $+4{ }^{\circ} \mathrm{C}$ терміном 7 діб. Щури групи III $(\mathrm{n}=6)$ одночасно з моделюванням ЕВУ отримували внутрішньочеревно 4\% розчин L-аргінін-L-глутамату (20 мг/100 г маси тіла). Для уточнення ролі NO-ергічного механізму дії L-аргінін-L-глутамату на кількісний склад муцинів та вільнорадикальні процеси, щурам з ЕВУ групи IV (n = 6) одночасно із ін'єкціями 4\% розчину L-аргінін-L-глутамату уводили неселективний інгібітор NO-синтази - LNAME (L-NG-nitroarginine methyl ester, 1 мг/100 г). По завершенні експерименту евтаназію проводили під кетаміновим наркозом у дозі 1 мг/100 г шляхом декапітації.

Досліджували кров, тканини шлунка, печінки, головного мозку щурів. У СО шлунка вміст загальних глікопротеїнів визначали методом I. I. Шелекетіної та співавт. (Rudenko et al., 2004). Рівень сіалових кислот вивчали за методом I. Warren у реакції з тіобарбітуровою кислотою, вміст фукози - за допомогою реакції із солянокислим цистеїном методом L. Dische, концентрацію гексозамінів - у реакції з ацетилацетоном у лужному середовищі методом R. Palmer (Prohorova, 1982). У крові, гомогенатах тканин шлунка, печінки, головного мозку, активність ПОЛ визначали за вмістом ТБК-активних продуктів у реакції з тіобарбітуровою кислотою (Ovsjannikova et al., 1999). У дослідних тканинах стан антиоксидантної системи визначали за рівнем відновленого глутатіону, що детермінували за реакцією Еллмана та показниками активності ферментів антиоксидантного захисту. Активність каталази (Кат) (КФ 1.11.1.6) оцінювали реакцією з молібдатом аммонію, глутатіонредуктази (ГР) (КФ 1.8.1.7) - за швидкістю окиснення НАДРН, глутатіонпероксидази (ГПО) (КФ 1.11.1.9) - методом, в основі якого лежить реакція взаємодії реактиву Еллмана з SН-групами (Barkovskij et al., 2013), супероксиддисмутази (СОД) (КФ 1.15.1.1) за інгібуванням відновлення нітросинього тетразолію (Pereslegina, 1989).

Статистичну обробку даних здійснювали за допомогою програмного пакета Statistica 6.0 (StatSoft Inc., США). Обчислювали середнє арифметичне (х) та стандартну похибку середнього арифметичного (SE). Достовірність відмінностей контрольної та дослідної груп оцінювали методом ANOVA. Вірогідним вважали відмінності на рівні $\mathrm{P}<0,05$.

\section{Результати}

Аналіз отриманих результатів свідчить, що моделювання ЕВУ у щурів II групи супроводжувалось зменшенням кількості загальних глікопротеїнів в 1,4 раза $(\mathrm{P}<0,05) 3$ одночасною зміною якісного складу шлункового слизу. Рівень сіалових кислот збільшився в 2,1 раза $(\mathrm{P}<0,05)$, а вміст фукози та гексозамінів зменшився в 1,3 і 1,9 раза, відповідно (Р < 0,05). Зазначені зміни СО шлунка відбувались за одночасної активації процесів ПОЛ у його тканині, про що свідчить збільшення кількості ТБК-активних продуктів у 2,0 раза $(\mathrm{P}<0,05)$ відносно показників контрольної групи (табл. 1).

У крові тварин групи II дія патогенних чинників інтенсифікувала вільнорадикальні реакції та дисбалансувала роботу антиоксидантної системи. Рівень ТБК-активних продуктів плазми крові збільшився на 56\% (P < 0,05), в еритроцитах - на 30\% $(\mathrm{P}<0,05)$ відносно контрольних індексів. Під час активації СОД на $32 \%$ (P < $0,05)$ одночасно збільшилась активність антиперекисних ензимів: каталази - на 18\% (P < 0,05), ГПО - на 66\% (P < 0,05) порівняно 3 аналогічними показниками групи контролю. Пул відновленого глутатіону виснажився в 1,3 раза $(\mathrm{P}<0,05)$, активність ензиму ГР, що має відновлювати окиснений глутатіон, залишалась без змін 
відносно до даних щурів групи I (табл. 2). У тканині печінки тварин групи ІІ відбулась інактивація СОД на $22 \%(\mathrm{P}<0,05)$ за одночасного зменшення активності ГПО на $20 \%(\mathrm{P}<0,05)$ та виснаження пулу відновленого глутатіону на $62 \%(\mathrm{P}<0,05)$, у результаті чого відбулось посилення процесів ПОЛ і зростання кількості ТБК-активних продуктів на $19 \%(\mathrm{P}<0,05)$ відносно відповідних контрольних показників (табл. 3). У тканині ГМ щурів групи II формування ЕВУ гастродуоденальної зони супроводжувалось зменшенням рівня відновленого глутатіону та активацією каталази в 1,5 раза $(\mathrm{P}<0,05)$ при тому, що активність інших ензимів антиоксидантного захисту не змінювалась, що спричинило значне накопичення продуктів ПОЛ. На це вказує зростання рівня ТБКактивних продуктів у 3,5 раза $(\mathrm{P}<0,05)$ порівняно $з$ відповідними контрольними показниками (табл. 4).

\section{Таблиця 1}

Склад муцинів і ПОЛ у шлунку тварин з ерозивно-виразковими ураженнями $(\mathrm{x} \pm \mathrm{SE}, \mathrm{n}=6)$

\begin{tabular}{|c|c|c|c|c|}
\hline Показники & Група I & Група II & Група III & Група IV \\
\hline Загальні глікопротеїни, мг/мл & $0,81 \pm 0,07$ & $0,58 \pm 0,03^{*}$ & $0,77 \pm 0,04^{* *}$ & $0,61 \pm 0,06^{*, * *+*}$ \\
\hline Фукоза, ммоль/л & $8,59 \pm 0,49$ & $6,80 \pm 0,47^{*}$ & $8,88 \pm 0,25^{* *}$ & $7,59 \pm 0,55$ \\
\hline Сіалові кислоти, ммоль/л & $1,10 \pm 0,05$ & $2,33 \pm 0,19^{*}$ & $1,48 \pm 0,14^{* *}$ & $1,18 \pm 0,08$ \\
\hline Гексозаміни, ммоль/л & $10,79 \pm 0,76$ & $5,68 \pm 0,35^{*}$ & $6,93 \pm 0,39 *$ & $3,16 \pm 0,35^{* * *+* k}$ \\
\hline ТБК-активні продукти, нмоль/г тканини & $4,46 \pm 0,39$ & $8,96 \pm 0,96^{*}$ & $6,39 \pm 0,67^{* *}$ & $8,75 \pm 0,47^{* *+*+*}$ \\
\hline
\end{tabular}

Примітки: * - P < 0,05 між контрольною (I) та дослідними групами; ** - P < 0,05 між показниками груп II та III; ***-P < 0,05 між групами III та IV.

Таблиця 2

Показники ПОЛ і антиоксидантної системи крові щурів з ерозивно-виразковими ураженнями $(\mathrm{x} \pm \mathrm{SE}, \mathrm{n}=6)$

\begin{tabular}{|c|c|c|c|c|c|}
\hline Показники & & Група I & Група II & Група III & Група IV \\
\hline ТБК-активні продукти, & плазма & $2,62 \pm 0,12$ & $4,19 \pm 0,42^{*}$ & $2,92 \pm 0,11^{* *}$ & $3,07 \pm 0,12^{*}$ \\
\hline нМоль/мл крові & еритроцити & $14,37 \pm 0,99$ & $18,61 \pm 1,15^{*}$ & $15,35 \pm 0,84$ & $18,32 \pm 0,98^{*}$ \\
\hline СОД, ум. од. & & $0,037 \pm 0,003$ & $0,049 \pm 0,003^{*}$ & $0,072 \pm 0,004^{*, * *}$ & $0,022 \pm 0,003^{*, * * * *}$ \\
\hline Каталаза, мМоль $\mathrm{H}_{2} \mathrm{O}_{2} / \mathrm{rHв} \bullet$ хв & & $3,58 \pm 0,13$ & $4,24 \pm 0,06^{*}$ & $3,63 \pm 0,12^{* *}$ & $2,89 \pm 0,08^{* * * * *}$ \\
\hline Відновлений глутатіон, мМоль/л & & $2,37 \pm 0,04$ & $1,81 \pm 0,04^{*}$ & $1,99 \pm 0,05^{*, * *}$ & $2,91 \pm 0,10^{*, * * *}$ \\
\hline ГПО, мМоль $\mathrm{H}_{2} \mathrm{O}_{2} / \mathrm{\Gamma Hв} \bullet$ хв & & $0,096 \pm 0,004$ & $0,160 \pm 0,003^{*}$ & $0,158 \pm 0,004^{*}$ & $0,091 \pm 0,005^{* * *}$ \\
\hline ГР, нМольНаДРН/гНв॰хв & & $0,39 \pm 0,01$ & $0,37 \pm 0,01$ & $0,44 \pm 0,02^{* *}$ & $0,23 \pm 0,01^{* * * * *}$ \\
\hline
\end{tabular}

Примітки: див. табл. 1.

Таблиця 3

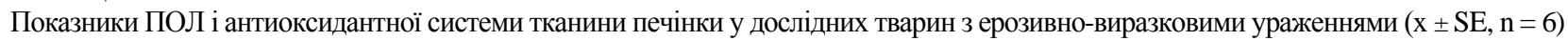

\begin{tabular}{|c|c|c|c|c|}
\hline Показники & Група I & Група II & Група III & Група IV \\
\hline ТБК-активні продукти, нМоль/Г & $4,00 \pm 0,27$ & $4,78 \pm 0,11^{*}$ & $4,34 \pm 0,08^{* *}$ & $6,40 \pm 0,52^{*, * * *}$ \\
\hline СОД, ум. од. & $0,80 \pm 0,05$ & $0,63 \pm 0,04^{*}$ & $0,75 \pm 0,04^{* *}$ & $0,46 \pm 0,03^{* * *+* k}$ \\
\hline Каталаза, мМоль $\mathrm{H}_{2} \mathrm{O}_{2} / \Gamma \cdot$ хв & $574,2 \pm 8,7$ & $572,1 \pm 9,5$ & $634,3 \pm 10,0^{*, * *}$ & $466,2 \pm 13,1^{* * * * *}$ \\
\hline Відновлений глутатіон, мМоль/л & $2,58 \pm 0,07$ & $0,99 \pm 0,05^{*}$ & $1,26 \pm 0,08^{* *}$ & $1,56 \pm 0,09^{*}$ \\
\hline ГПО, мМоль $\mathrm{H}_{2} \mathrm{O}_{2} / \Gamma^{\bullet} \mathrm{xв}$ & $19,70 \pm 0,81$ & $15,89 \pm 0,44^{*}$ & $17,19 \pm 0,89^{*}$ & $14,75 \pm 0,89^{*}$ \\
\hline ГР, мкМольНаДРН/г•хв & $0,048 \pm 0,001$ & $0,046 \pm 0,001$ & $0,047 \pm 0,001$ & $0,030 \pm 0,001^{*, *+* * *}$ \\
\hline
\end{tabular}

Примітки: див. табл. 1.

Таблиця 4

Показники ПОЛ і антиоксидантної системи тканини головного мозку щурів з ерозивно-виразковими ураженнями $(\mathrm{x} \pm \mathrm{SE}, \mathrm{n}=6)$

\begin{tabular}{|c|c|c|c|c|}
\hline Показники & Група I & Група II & Група III & Група IV \\
\hline ТБК-активні продукти, нМоль/Г & $1,64 \pm 0,07$ & $5,69 \pm 0,14^{*}$ & $5,15 \pm 0,19^{*}$ & $5,84 \pm 0,39^{*}$ \\
\hline СОД, ум. од. & $0,47 \pm 0,03$ & $0,50 \pm 0,03$ & $0,83 \pm 0,04^{* * * *}$ & $0,50 \pm 0,06^{* * *}$ \\
\hline Каталаза, мМоль $\mathrm{H}_{2} \mathrm{O}_{2} / \Gamma \cdot$ хв & $89,0 \pm 6,1$ & $133,9 \pm 6,1^{*}$ & $190,7 \pm 9,5^{* * * *}$ & $73,1 \pm 3,5^{* * * k}$ \\
\hline Відновлений глутатіон, мМоль/л & $1,14 \pm 0,04$ & $0,37 \pm 0,03^{*}$ & $0,80 \pm 0,03^{* * * *}$ & $1,26 \pm 0,07^{* * *}$ \\
\hline ГПО, мМоль $\mathrm{H}_{2} \mathrm{O}_{2} / \Gamma \bullet$ хв & $11,05 \pm 0,65$ & $10,54 \pm 0,45$ & $15,39 \pm 0,88^{* * * *}$ & $8,28 \pm 0,79^{*, *+*}$ \\
\hline ГР, мкМольНаДРН/г•хв & $0,050 \pm 0,001$ & $0,050 \pm 0,001$ & $0,065 \pm 0,002^{*, * *}$ & $0,028 \pm 0,001^{* * * * *}$ \\
\hline
\end{tabular}

ГР, мкМольНаДРН/г•хв

Примітки: див. табл. 1.

Ін'єкції L-аргінін-L-глутамату у тварин з EBУ сприяли збільшенню кількості загальних глікопротеїнів відносно показників щурів групи II - в 1,3 раза $(\mathrm{P}<0,05)$. Рівні фукози та сіалових кислот у тварин групи III відновились до контрольних значень, але вміст гексозамінів залишився нижчим за контрольні індекси, хоча і зростав відносно відповідних даних щурів групи II на $22 \%$ (P < 0,05). Процеси ПОЛ у тканині шлунка тварин групи III уповільнювались за дії L-аргінін-L-глутамату, кількість ТБК-активних продуктів знижувалась на $29 \%(\mathrm{P}<0,05)$ відносно індексів щурів групи II (табл. 1).

У крові тварин групи III спостерігали подальшу активацію ензиму першої ланки АОЗ - СОД на 47\% (P < 0,05) порівняно 3 даними щурів групи II. Активність каталази зменшилась до контрольних значень, тоді як активність іншого антиперекисного ензиму - ГПО залишився значно вищим за рівні аналогічного індексу щурів групи II. Активація ГР на $19 \%$ (P < 0,05) сприяла поповненню пулу відновленого глутатіону на $10 \%$ (P < 0,05). Зазначені зміни в системі $\mathrm{AO} 3$ у крові щурів групи III супроводжувались зниженням інтенсивності вільнорадикальних процесів, про що свідчить зменшення кількості ТБК-активних продуктів у плазмі на $31 \%$ ( $>0,05)$ відповідно до показника щурів групи II (табл. 2).

У тканині печінки щурів групи III за впливу L-аргінін-L-глутамату відбулась достовірна активація ферментативної антиоксидантної ланки: СОД - на 20\% (P < 0,05), каталази - на $11 \%$ ( $0,05)$ відносно відповідних даних тварин групи II. Кількість відновленого глутатіону зросла на $27 \%(\mathrm{P}<0,05)$, рівень ТБК-активних продуктів знизився на 9\% (P < 0,05) порівняно з аналогічними індексами групи II (табл. 3).

У тканині головного мозку введення L-аргінін-L-глутамату у щурів групи III активувало ензими першої ланки захисту - СОД на 66\% (P < 0,05), каталази - на 42\% (P < 0,05), ГПО - на 46\% (P < 0,05). Активація ГР на $30 \%(\mathrm{P}<0,05)$ сприяла підвищенню пулу відновленого глутатіону в 2,2 раза $(\mathrm{P}<0,05)$ відносно відповідних показників тварин групи II. Проте, активація систем АОЗ у мозку щурів групи III не сприяла зменшенню інтенсивності процесів ПОЛ, про що свідчить відсутність кількісних змін ТБК-активних продуктів у тканині головного мозку щурів групи III (табл. 4). Одночасні ін'єкції L-аргінін-L-глутамату та L-NAME у щурів групи 
IV в CO шлунка нівелювали ефекти ізольованого впливу L-аргінін-L-глутамату, про що свідчить зниження кількості загальних глікопротеїнів на $21 \%(\mathrm{P}<0,05)$ зі зміною якісного складу слизу: мали місце тенденції до зменшення кількості фукози та достовірне зниження гексозамінів у 2,2 раза $(\mathrm{P}<0,05)$, відносно відповідних індексів тварин групи ІІІ. Уведення неселективного інгібітору сприяло різкому накопиченню продуктів ПОЛ у тканині шлунка: рівень ТБК-активних продуктів зростав на $37 \%$ (P < 0,05) відносно показників тварин групи III (табл. 1).

У крові щурів групи IV спостерігали інактивацію ферментативної ланки АОЗ - СОД у 3,2 раза $(\mathrm{P}<0,05)$, каталази - на $21 \%$ ( $<<0,05)$, ГПО - на 43\% (P < 0,05), ГР - на 48\% ( $<<0,05)$. Одночасно зростав рівень відновленого глутатіону - на 46\% (P < 0,05), відносно аналогічних даних тварин групи ІІІ (табл. 2).

У печінці тварин групи IV активація ПОЛ відбулась зі збільшенням ТБК-активних продуктів на $47 \%(\mathrm{P}<0,05)$ на тлі інактивації СОД на $39 \%$ (Р < 0,05), каталази - на 27\% (P < 0,05) та ГР на $37 \%(\mathrm{P}<0,05)$ відповідно до показників тварин групи III (табл. 3).

У тканині мозку щурів групи IV також мала місце достовірна інактивація антиоксидантних ензимів: СОД - на 40\% (P < 0,05), каталази - у 2,6 раза $(\mathrm{P}<0,05)$, ГПО - на $46 \%(\mathrm{P}<0,05)$, ГР - на $56 \%$ (P $<0,05)$ за збільшення пулу відновленого глутатіону на 57\% $(\mathrm{P}<0,05)$ відносно відповідних індексів тварин групи ІІІ (табл. 4).

\section{Обговорення}

Моделювання ЕВУ гастродуоденальної зони шляхом інтрагастрального введення медичної жовчі за поєднаної дії імобілізаційно-холодового стресування в експериментальних тварин викликало посилення вільнорадикальних процесів у всіх дослідних тканинах. При цьому високий рівень ТБК-активних продуктів у крові, тканинах шлунка, печінки та головному мозку свідчить про розвиток у них оксидативного стресу. Патогенний вплив жовчі на СО шлунка реалізується завдяки детергентним властивостям жовчних кислот, основною мішенню для яких виступають ліпідні компоненти слизу - фосфоліпіди, що забезпечують гідрофобність слизового шару (Yandrapu \& Sarosiek, 2015). Фосфоліпіди значно підвищують в'язкість і проникність слизу, впливають на якість захисних муцинів. Плівка поверхнево-активних фосфоліпідів на поверхні СО захищає структурні компоненти шлунка від зворотної дифузії $\mathrm{H}^{+}$-іонів із його просвіту. Дія $\mathrm{H}^{+}$-іонів викликає структурні порушення СО та їі мікроциркуляторної ланки. В результаті мають місце гіпоксичні явища, що надалі супроводжуються розвитком оксидативного стресу. Іммобілізаційно-холодове стресування дослідних щурів через механізми норадренергічної стимуляції додатково посилює ПОЛ. Дія пошкоджувальних факторів на СО шлунка експериментальних тварин порушувала синтез і якісний склад секреторних муцинів. Зниження кількості загальних глікопротеїнів супроводжувалось кількісними змінами їх вуглеводних компонентів. Олігосахариди муцинів можуть складати до 90\% загальної молекулярної маси зрілого глікопротеїну. Біохімічні властивості та функції муцинів, насамперед, залежать від складу О-гліканів. Процес глікозилювання муцинів відбувається за дії родини ензимів глікозілтрансфераз, що мають свій власний набір кінетичних властивостей і субстратну специфічність, контролюють і жорстко регулюють вуглеводний профіль на апомуцині. Саме зміни активності глікозілтрансфераз за патологічних процесів викликають утворення нехарактерних глікопротеідів (Duarte et al., 2016). Гексозаміни та фукоза - основні компоненти у складі муцинів шлунка, які виконують захисну роль проти інфекційних патогенів. Запалення СО супроводжується зсувом профілю глікозилювання 3 превалюванням негативно заряджених гліканових фрагментів, насамперед, сіалових кислот. Існують дослідження, що свідчать про роль медіаторів запалення у регуляції транскрипції генів муцинів, що утворюють гель (Zolotova, 2014).

За аналізу отриманих даних розвиток оксидативного стресу у дослідних тваринах має тканиноспецифічні особливості. У крові тварин з ЕВУ активація ферментативної ланки АОЗ не компенсувала вільнорадикальних процесів, у результаті відбувалось висна- ження пулу відновленого глутатіону, а рівень ТБК-активних продуктів зростав як у плазмі, так і в еритроцитах. Еритроцити - високо спеціалізовані клітини, що відповідають за транспорт кисню 3 легень у тканини. Наявність високих концентрацій молекулярного кисню та заліза в гемовій групі еритроцитів становить потенційну загрозу утворення високо реакційних кисневих метаболітів. Генерація АФК в еритроцитах, насамперед, пов'язана $з$ аутоокисненням гемоглобіну $(\mathrm{Hb})$ в метгемоглобін $(\mathrm{MetHb})$, в результаті чого продукується супероксидний аніон $\left(\mathrm{O}^{2-}\right)$, який за участі СОД дисмутує у перекис водню $\left(\mathrm{H}_{2} \mathrm{O}_{2}\right)$, що може вступати в реакцію 3 іншим $\mathrm{O}^{2-}$ або реагувати із залізом у формі $\mathrm{Fe}^{2+}$ (реакції Фентон). Продукт обох реакцій - токсичний гідроксильний радикал, здатний пошкоджувати клітинні білки та поліненасичені мембранні ліпіди, що, у свою чергу, викликає функціональні та структурні порушення еритроцитів (van Zwieten et al., 2014). Вільнорадикальні продукти аутоокиснення $\mathrm{Hb}$, що утворюються саме на еритроцитарній мембрані, відносно недоступні для переважно цитозольної антиоксидантної системи еритроцитів. Каталаза не може конкурувати з $\mathrm{Hb}$ за взаємодії $3 \mathrm{H}_{2} \mathrm{O}_{2}$, який утворюється на еритроцитарній мембрані, тоді як вирішальну роль у нейтралізації АФК, генерованих на мембрані еритроцитів, відіграє ГПО. На ефективність капілярного кровообігу та постачання кисню до тканин впливає функціональна повноцінність еритроцитів, яка визначається механічними властивостями мембрани, достатнім рівнем АТФ і кисневотранспортною функцією гемоглобіну. Підтримання кровотоку в капілярах залежить від здатності еритроцитів до деформації. За дії оксидативного стресу відбувається ушкодження мембранних білків, у тому числі мембран цитоскелету, які відповідають за деформованість червоних кров'яних тілець (Mohanty et al., 2014). Перебудова метаболізму еритроцитів - одна з причин розвитку гіпоксичних змін у СО шлунка.

У тканині печінки тварин з ЕВУ гастродуоденальної зони спостерігали депресію ензимів антиоксидантної ланки та зменшення рівня відновленого глутатіону, що свідчить про декомпенсацію печінкових систем АОЗ. Печінка - орган, який виконує метаболічну функцію та бере участь в обміні білків, вуглеводів, жирів, гормонів, вітамінів, у процесах знешкодження та детоксикації ендогенних і екзогенних речовин. Висока активність метаболічних процесів у печінці робить її клітини основними мішенями для АФК. Мітохондрії, мікросоми та пероксисоми в паренхіматозних клітинах печінки - потенційні генератори вільних радикалів і АФК. Порушення редокс-гомеостазу у печінці індукують незворотні зміни клітинних ліпідів, білків, ДНК, та, що важливо, модулюють шляхи, які контролюють нормальні біологічні функції (Li et al., 2015). Найважливіший неферментативний гідрофільний антиоксидант у печінці - глутатіон, трипептид, $\gamma$-L-глутаміл-L-цистеінілгліцин, найпоширеніший небілковий тіол. Глутатіон представлений у клітинах у тіол-відновленій (відновлений глутатіон) і дисульфідокисленій формах. Відновлений глутатіон синтезується тільки в цитоплазмі всіх клітин ссавців. Проте центральний орган його синтезу - печінка. Відновлений глутатіон синтезується in vivo у дві стадії шляхом послідовної дії двох АТФ-залежних ензимів із амінокислот-попередників цистеїна, глутамата та гліцина. Перша реакція синтезу відновленого глутатіону - утворення $\gamma$-глутаміл-Lцистеїну за допомогою ферменту $\gamma$-глутамілцистеїнлігази - гетеродимеру, який складається $з$ двох субодиниць - важкої каталітичної (GCLC) та легкої модуляторної (GCLM), що кодуються різними генами, у складі яких $є$ антиоксидант-електрофіл-респонсивний елемент (ARE), що забезпечує їх редокс-регуляцію. GCLC демонструє всю каталітичну активність холоензиму та інгібується за типом зворотнього зв'язку відновленого глутатіоном, що зв'язується 3 глутаматним сайтом ферменту. GCLM значно знижує $\mathrm{K}_{\mathrm{M}}$ для глутамата та інгібувального ефекту відновленого глутатіону. За фізіологічних умов регуляція $\gamma$-глутамілцистеїнлігази здійснюється неаллостеричним зворотнім зв'язком із відновленим глутатіоном і біодоступністю L-цистеїну, який у високих концентраціях токсичний. Друга реакція синтезу відновленого глутатіону відбувається за впливу глутатіонсинтетази, що каталізує взаємодію $\gamma$-глутаміл-L-цистеїну з L-гліцином. Слід відмітити, що $\gamma$-глу- 
тамілцистеїнлігаза лімітує швидкість синтезу відновленого глутатіону. Центральна роль печінки у цьому синтезі, насамперед, пов'язана 3 доступністю цистеїну. Саме у печінці метаболізуються амінокислоти, отримані з раціону, та відбувається транссульфутування метіоніну з утворенням цистеїну (Chen et al., 2013; Shelly \& $\mathrm{Lu}, 2013)$. Після синтезу в цитоплазмі глутатіон за допомогою мембранних транспортерів проникає в інші компартменти клітин (мітохондрії, ядро та ендоплазматичний ретикулум, де, за винятком останнього, знаходиться у відновленій формі). В ендоплазматичному ретикулумі окиснена форма глутатіону необхідна для правильного складання та секреторного шляху білків. Крім того, можливий міжклітинний та міжорганний транспорт глутатіону. Синтезований у печінці глутатіон вивільняється у плазму крові через синусоїдну мембрану. В нормі експорт глутатіону переважає його метаболізм у печінці. 20\% синтезованого у печінці глутатіону в окисненій формі вивільняється через каналікулярну мембрану в жовч, де його концентрація значно вища, ніж у печінці.

Печінка - основне, але не єдине джерело відновленого глутатіону. У крові глутатіон не метаболізується. Це відбувається після його надходження в клітини (Kulinskij \& Kolesnichenko, 2009). На відміну від синтезу, катаболізм відновленого глутатіону та його аддуктів відбувається винятково у позаклітинному просторі на поверхні клітинних мембран, які експресують ензим $\gamma$-глутамілтрансферазу. Даний ензим гідролізує відновлений глутатіон до глутамінової кислоти та дипептида цистеїнілгліцина, що, у свою чергу, гідролізується дипептидазами до складових амінокислот, які далі поглинаються клітинами для подальшого метаболізму або ресинтезу. Можна констатувати, що рівень внутрішньоклітинного та позаклітинного відновленого глутатіону визначається балансом між його виробництвом, споживанням і транспортуванням. У зв'язку з важливістю його фізіологічних функцій ці процеси жорстко регулюються. Активність ензимів, що беруть участь у метаболізмі відновленого глутатіону, контролюється на транскрипційних, трансляційних і посттрансляційних рівнях. У нашому експерименті падіння рівня відновленого глутатіону у клітинах печінки щурів 3 ЕВУ гастродуоденальної зони за незміненої активності ГР, вірогідно, може відбуватися як за збільшення синусоїдного відтоку та міжорганного перерозподілу, так і за інгібування синтезу.

Розвиток цієї патології в експериментальних тварин супроводжується дестабілізацією окисно-відновних процесів у тканині головного мозку, що інтенсифікувало ПОЛ. Зазначені зміни, насамперед, пов'язані з дією пошкоджувальних патогенних чинників, що викликали надмірне подразнення вісцерорецепторів шлунка та супроводжувались зміною активності центральних регуляторних структур, пов'язаних із прийняттям і переробкою цих сигналів. Окисний стрес може викликати пряме пошкодження клітин головного мозку. За нормальних фізіологічних умов мозок ссавців споживає близько 20\% загальної кількості кисню в організмі. Головний мозок значно збагачений поліненасиченими жирними кислотами, важливими для нейронних функцій та чутливими до атаки АФК. Системи ж АОЗ у головному мозку доволі нечисленні (Ren et al., 2017). У нашому експерименті під час моделювання ЕВУ гастродуоденальної зони в його тканині відбувалась лише активація каталази (присутня лише в пероксисомах), що свідчить про високу концентрацію $\mathrm{H}_{2} \mathrm{O}_{2}$. Але основне джерело у клітинах головного мозку - мітохондрії, де каталаза відсутня, а основний захисний ензим - ГПО. Вірогідно, активація ГПО лімітувалася низькою концентрацією в головному мозку відновленого глутатіону.

Iн'єкції L-аргінін-L-глутамату, які отримували експериментальні щури одночасно з моделюванням ЕВУ, нормалізували кількість загальних глікопротеїнів у СО шлунка з одночасним відновленням складових вуглеводних компонентів муцинів і зменшенням процесів ліпопероксидації. Зазначені зміни, на нашу думку, насамперед пов'язані з роботою системи L-аргінін-NO. Для підтвердження цієї гіпотези використано неселективний блокатор NO-синтази - L-NAME, який уводили одночасно з L-аргінін-Lглутаматом. Уведення блокатору нівелювало отриманий результат впливу L-аргінін-L-глутамату в CO: рівень ТБК-активних продуктів і загальних глікопротеїнів незначно відрізнявся від показни- ків тварин з ЕВУ, які не отримували L-аргінін-L-глутамат; кількість основних вуглеводних структурних компонентів муцинів гексозамінів, була значно меншою порівняно зі щурами з ЕВУ.

Вплив L-аргінін-L-глутамату у щурів з EBУ викликав ідентичні зміни системи АОЗ у дослідних тканинах, що виражалось збалансованою активацією антирадикального ензиму СОД і антиперекисного ГПО. Одночасно спостерігали поповнення пулу ВГ і уповільнення процесів ПОЛ у крові та тканині печінки, тоді як у тканині головного мозку активація систем АO3 не сприяла інгібуванню процесів ПОЛ, що, вірогідно, пов'язане із занадто інтенсивними стресорами, які застосовували під час моделювання ЕВУ. Зростання рівня відновленого глутатіону за впливу L-аргінін-Lглутамату в крові та тканині головного мозку відбувалось за участі ГР, про що свідчить іï активація, а у тканині печінки основним механізмом поповнення пулу відновленого глутатіону, на нашу думку, був синтез de поvo. Застосування L-NAME інгібувало всі ферменти $\mathrm{AO}$, що свідчить про взаємні регуляторні механізми антиоксидантної системи та NO.

Відома роль $\mathrm{NO}$ як поглинача $\mathrm{O}^{2-}$ з утворенням пероксинитриту $\left(\mathrm{ONOO}^{-}\right)$, причому константа взаємодії даної реакції більша, ніж за дисмутації $\mathrm{O}^{2-}$, що каталізується СОД. Окрім відомої пошкоджувальної дії, $\mathrm{ONOO}^{-}$може впливати на метаболізм відновленого глутатіону, з утворенням нітрозоглутатіону (GSNO), що признаний як ендогенний резервуар NO. GSNO здатний до експорту з клітин через мембранні транспортери відновленого глутатіону. Припускають, що в реакціях утворення GSNO саме концентрація відновленого глутатіону критична під час взаємодії з NOсистемою (Keszler et al., 2010; Broniowska et al., 2013). Вивчаються механізми вивільнення $\mathrm{NO}_{3} \mathrm{GSNO}$. Існує гіпотеза, що розкладання GSNO відбувається за присутності відновленого глутатіону та каталізується $\mathrm{Zn} / \mathrm{Cu}-\mathrm{COД}$ (Kolesnik et al., 2013).

Застосування неселективного інгібітору NO у тварин з ЕВУ дозволяє зробити припущення, що під час блокування NO-системи відбувається вивільнення NO з GSNO, про що свідчить стабільний рівень відновленого глутатіону у тканинах печінки та головному мозку, і його зростання у крові на тлі загальної депресії AO3 і активації ПОЛ. Припускаємо, що поповнення пулу відновленого глутатіону в умовах інгібування ГР відбувалось за рахунок синтеза de поvо з використанням уведеного L-глутамату. Wu (1998) повідомляє, що саме люмінальний глутамат, а не глутамат, отриманий із глютаміну, - пріоритетне джерело для синтезу відновленого глутатіону.

Одна 3 основних функцій відновленого глутатіону та GSNO модулювальний вплив на процеси оксигенації, деоксигенації крові в капілярах і на спорідненість гемоглобіну до кисню. Циркулюючий у крові NO зв'язується з гемоглобіном у формі S-нітрозотіолу, а саме S-нітрозогемоглобіну (SNO-Hb). S-нітрозування $\mathrm{Hb}$ полегшує від'єднання $\mathrm{NO}$ з гему, регулюється алостерично та функціонально пов'язане 3 приєднанням $\mathrm{O}_{2}$. Під час зв'язування $\mathrm{Hb} 3$ $\mathrm{O}_{2}$ у легенях його спорідненість для S-нитрозотіолу зростає, а під час віддачі - знижується, в результаті чого NO вивільняється у тканини. Припускають, що за реакції SNO-Hb із відновленим глутатіоном відбувається модифікація спорідненості гемоглобіну до кисню, зсув кривої дисоціації оксигемоглобіну вправо, вивільнення кисню. Вплив SNO-Hb на транспорт NO до тканин досить істотний, оскільки вивільнення $\mathrm{NO}$ з комплексу з Нb суттєво залежить від наявності або відсутності кисню. Саме в гіпоксичних умовах $\mathrm{Hb}$ переходить із R- в T-конформацію, в якій він не може міцно утримувати NO (Robaczewska et al., 2016).

Підсумовуючи, можна констатувати, що L-аргінін-L-глутамат через NO-залежні механізми під час поєднаного впливу на AO3, зокрема, на систему відновленого глутатіону, може модулювати стан мікроциркуляторної системи у слизовій оболонці шлунка, що викликає відновлення факторів іiі захисту.

\section{Висновки}

Моделювання ерозивно-виразкових уражень гастродуоденальної зони в експериментальних тварин супроводжується інтен- 
сифікацією процесів ПОЛ, дисбалансом роботи систем антиоксидантного захисту та розвитком оксидативного стресу в крові, тканинах шлунка, печінки, головного мозку. У слизовій оболонці шлунка експериментальних тварин зменшується загальна кількість факторів захисту - секреторних муцинів з одночасною їх структурною зміною. Застосування L-аргінін-L-глутамату зменшує прояву оксидативного стресу у тканині шлунка тварин з експериментальною патологією та нормалізує кількісний і якісний склад муцинів. У крові, тканинах печінки, головного мозку щурів ін'єкції L-аргініну-L-глутамату сприяли активації ензимів першої антирадикальної ланки - супероксиддисмутази та каталази, збільшенню пулу відновленого глутатіону та уповільненню вільнорадикальних реакцій. Дослідження реакцій на дію інгібітору дає підстави для гіпотези про NO-опосередкований механізм впливу Lаргінін-L-глутамату з утворенням S-нітрозотіолів, про що свідчить високий рівень відновленого глутатіону під час його застосування.

\section{References}

Amagase, K., Nakamura, E., Kato, S., \& Takeuchi, K. (2015). Glutamate as a potential protective drug in the gastrointestinal mucosa. Yakugaku Zasshi, 135(6), 779-782.

Babak, O. J., Frolov, V. M., \& Harchenko, N. V. (2005). Glutargin - farmakologicheskoe dejstvie i klinicheskoe primenenie [Glutargin - pharmacological action and clinical application]. Jelton-2, Kharkov (in Russian).

Barinov, E. F., Kondratenko, P. G., Sulaeva, O. N., Jarikov, S. O., \& Delyy, V. Y. (2013). Gastrointestinal'nyy bar'yer: Struktumyye i molekulyarnyye determinanty v norme i pri ul'tserogeneze [Gastrointestinal barrier: Structural and molecular determinants in norm and in ulcerogenesis]. Ukrayinskyy Zhurnal Khirurhiyi, 23(4), 96-104 (in Russian).

Bhattacharyya, A., Chattopadhyay, R., Mitra, S., \& Crowe, S. E. (2014). Oxidative stress: An essential factor in the pathogenesis of gastrointestinal mucosal diseases. Physiological Reviews, 94(2), 329-354.

Broniowska, K. A., Diers, A. R., \& Hogg, N. (2013). S-nitrosoglutathione. Biochimica Biophysica Acta, 1830(5), 3173-3181.

Chen, Y., Dong, H., Thompson, D. C., Shertzer, H. G., Nebert, D. W., \& Vasiliou, V. (2013). Glutathione defense mechanism in liver injury: Insights from animal models. Food and Chemical Toxicology, 60, 38-44.

Cossenza, M., Socodato, R. C., Portugal, C. C., Domith, I. C., Gladulich, L. F., Encarnação, T. G., Calaza, K. C., Mendonça, H. R., Campello-Costa, P., \& Paes-de-Carvalho, R. (2014). Nitric oxide in the nervous system: Biochemical, developmental, and neurobiological aspects. Vitamins and Hormones, 96, 79-125.

Duarte, H. O., Freitas, D., Gomes, C., Gomes, J., Magalhães, A., \& Reis, C. (2016). Mucin-type O-glycosylation in gastric carcinogenesis. Biomolecules, 6(3), 33.

El-Demerdash, E., El-Mesallamy, H. O., Abu-Zaid, N. M., \& Gad, M. Z. (2010). The potential therapeutic effect of nitric oxide modulators in experimentallyinduced gastric ulcers. Drug Discoveries and Therapeutics, 4(4), 276-284.

Gyires, K., Toth, V. E., \& Zadori, Z. S. (2015). Gastric mucosal protection: From the periphery to the central nervous system. Jornal of Physiology and Pharmacolology, 66(3), 319-329.

Hlynov, I. B., \& Chikunova, M. V. (2016). Znacheniye slizisto-bikarbonatnogo bar'yera zheludka pri kislotnozavisimykh zabolevaniyakh [The role of gastric mucus-bicarbonate barrier in acid diseases]. Russkij Medicinskij Zhurnal, 17, 1125-1129 (in Russian).

Ishibashi-Shiraishi, I., Shiraishi, S., Fujita, S., Ogawa, S., Kaneko, M., Suzuki, M., \& Tanaka, T. (2016). L-arginine L-glutamate enhances gastric motor function in rats and dogs and improves delayed gastric emptying in dogs. Journal of Pharmacology and Experimental Therapeutics, 359(2), 238-246.

Jiménez, M. D., Martín, M. J., Alarcón de la Lastra, C., Bruseghini, L., Esteras, A., Herrerías, J. M., \& Motilva, V. (2004). Role of L-arginine in ibuprofeninduced oxidative stress and neutrophil infiltration in gastric mucosa. Free Radical Research, 38(9), 903-911.

Keszler, A., Zhang, Y., \& Hogg, N. (2010). Reaction between nitric oxide, glutathione, and oxygen in the presence and absence of protein: How are S-nitrosothiols formed? Free Radical Biology and Medicine, 48(1), 55-64.

Kim, S. F. (2014). The nitric oxide-mediated regulation of prostaglandin signaling in medicine. Vitamins and Hormones, 96, 211-245.

Kirichuk, V. F., Andronov, E. V., Ivanov, A. N., \& Mamontova, N. V. (2008). Oksid azota i mikrocirkuljatornoe zveno sistemy gemostaza (obzor literatury) [Nitric oxide and microcirculatory unit of the hemostasis system (literature review)]. Uspehi Fiziologicheskih Nauk, 39(4), 83-91 (in Russian).

Kolesnik, B., Palten, K., Schrammel, A., Stessel, H., Schmidt, K., Mayer, B., \& Gorren, A. C. (2013). Efficient nitrosation of glutathione by nitric oxide. Free Radical Biology and Medicine, 63, 51-64.
Kulinskij, V. I., \& Kolesnichenko, L. S. (2009). Sistema glutationa. I. Sintez, transport, glutationtransferazy, glutationperoksidazy [Glutathione system. I. Synthesis, transport, glutathione transferase, glutathione peroxidase]. Biomedicinskaja Himija, 55(3), 255-277 (in Russian).

Kumar, S., Singh, R. K., \& Bhardwaj, T. R. (2017). Therapeutic role of nitric oxide as emerging molecule. Biomedicine and Pharmacotherapy, 85(1), 182-201.

Kunio, T., Hisayuki, U., \& Eiji, N. (2013). Physiological roles of dietary glutamate signaling via gut-brain axis due to efficient digestion and absorption. Journal of Gastroenterology, 48(4), 442-451.

Kwiecien, S., Jasnos, K., Magierowski, M., Sliwowski, Z., Pajdo, R., Brzozowski, B., Mach, T., Wojcik, D., \& Brzozowski, T. (2014). Lipid peroxidation, reactive oxygen species and antioxidative factors in the pathogenesis of gastric mucosal lesions and mechanism of protection against oxidative stress-induced gastric injury. Journal of Physiology and Pharmacology, 65(5), 613-622.

Larsson, J. M., Thomsson, K. A., Rodríguez-Piñeiro, A. M., Karlsson, H., \& Hansson, G. C. (2013). Studies of mucus in mouse stomach, small intestine, and colon. III. Gastrointestinal Muc5ac and Muc2 mucin O-glycan patterns reveal a regiospecific distribution. American Joumal of Physiology Gastrointestinal and Liver Physiology, 305(5), 357-363.

Lei, J., Vodovotz, Y., Tzeng, E., \& Billiar, T. R. (2013). Nitric oxide, a protective molecule in the cardiovascular system. Nitric Oxide, 35, 175-185.

Li, S, Tan, H. Y., Wang, N., Zhang, Z. J., Lao, L., Wong, C. W., \& Feng, Y. (2015). The role of oxidative stress and antioxidants in liver diseases. International Journal of Molecular Sciences, 16(11), 26087-26124.

Lundberg, J. O., \& Weitzberg, E. (2012). Biology of nitrogen oxides in the gastrointestinal tract. Gut, 62(4), 616-629.

Lykholat, T., Lykholat, O., \& Antonyuk, S. (2016). Immunohistochemical and biochemical analysis of mammary gland tumours of different age patients. Cytology and Genetic, 50(1), 32-41.

Lykholat, O. A., Grigoryuk, I. P., \& Lykholat, T. Y. (2016). Metabolic effects of alimentary estrogen in different age animals. Annals of Agrarian Science, 14(4), 335-339.

Magierowski, M., Magierowska, K., Slawomir Kwiecien, S., \& Brzozowski, T. (2015). Gaseous mediators nitric oxide and hydrogen sulfide in the mechanism of gastrointestinal integrity, protection and ulcer healing. Molecules, 20(5), 9099-9123.

Matsui, H., Nagano, Y., Shimokawa, O., Kaneko, T., Rai, K., Udo, J., Hirayama, A., Nakamura, Y., Indo, H. P., Majima, H. J., \& Hyodo, I. (2011). Gastric acid induces mitochondrial superoxide production and lipid peroxidation in gastric epithelial cells. Journal of Gastroenterology, 46(10), 1167-1176.

Mohanty, J. G., Nagababu, E., \& Rifkind, J. M. (2014). Red blood cell oxidative stress impairs oxygen delivery and induces red blood cell aging. Frontiers in Physiology, 28(5), 84

Ovsjannikova, M. M., Al'ohina, S. M., \& Drobins'ka, O. V. (1999). Biohimichni ta biofizichni metodi ocinki porushen' okisljuval'nogo gomeostazu v osib, sho zaznali radiacijnogo vplivu vnaslidok avariï na ChAES [Biochemical and biophysical methods for evaluating the disturbances of oxidative homeostasis in persons who have undergone radiation influence as a result of the Chemobyl accident]. Kyiv (in Russian).

Pen, X., Zou, L., Zhang, X., Branco, V., Wang, J., Carvalho, C., Holmgren, A., \& Lu, J. (2017). Redox signaling mediated by thioredoxin and glutathione systems in the central nervous system. Antioxidants and Redox Signaling, 27(13), 989-1010.

Pereslegina, I. A. (1989). Aktivnost' antioksidantnyh fermentov sljuny u zdorovyh detej [Activity of antioxidant saliva enzymes in healthy children]. Laboratornoe Delo, 11, 20-23 (in Russian).

Pérez, S., Taléns-Visconti, R., Rius-Pérez, S., Finamor, I., \& Sastre, J. (2017). Redox signaling in the gastrointestinal tract. Free Radical Biology and Medicine, 104, 75-103.

Robaczewska, J., Kedziora-Komatowska, K., Kozakiewicz, M., Zary-Sikorska, E., Pawluk, H., Pawliszak, W., \& Kedziora, J. (2016). Role of glutathione metabolism and glutathione-related antioxidant defense systems in hypertension. Jomal of Physiology and Pharmacology, 67(3), 331-337.

Prohorova, M. I. (Ed.). (1982). Metody biohimicheskih issledovanij (lipidnyj i jenergeticheskij obmen) [Methods of biochemical research (lipid and energy metabolism)]. Leningradskij Universitetet, Leningrad (in Russian).

Rudenko, A. I., Majkova, T. V., Mosijchuk, L. M., Ponomarenko, O. A., Tolstikova, T. M., \& Sirotenko, A. S. (2004). Kliniko-laboratorna ocinka funkcional'nogo stanu sekretornih zaloz shlunka [Clinical and laboratory evaluation of functional state of the secretory glands of the stomach]. Kyiv (in Russian).

Semenchuk, S. A., Jakovleva, O. A., \& Stockaja, T. V. (2017). Jeffektivnost' primenenija L-arginina-L-glutamata kak metabolicheskogo korrektora u bol'nyh s postinfarktnym kardiosklerozom [The efficacy of L-arginine-L-glutamate as a metabolic corrector in patients with postinfarction cardiosclerosis]. Bukovyns'kyj Medychnyj Visnyk, 21(1), 132-135 (in Russian).

Sgambato, D., Capuano, A., Sullo, M. G., Miranda, A., Federico, A., \& Romano, M. (2016). Gut-brain axis in gastric mucosal damage and protection. Current Neuropharmacology, 14(8), 959-966. 
Sulaeva, O. N. (2015). Struktumaja organizacija i fiziologicheskie jeffekty bluzhdajushhego nerva v ZhK [Structural organization and physiological effects of the vagus nerve in the GIT]. Svit Medycyny ta Biologiyi, 53(4), 164-171 (in Russian).

Shelly, C., \& Lu, M. D. (2013). Glutathione synthesis. Biochimica et Biophysica Acta, 1830(5), 3143-3153.

Taché, Y. (2012). Brainstem neuropeptides and vagal protection of the gastric mucosal against injury: Role of prostaglandins, nitric oxide and calcitoningene related peptide in capsaicin afferents. Current Medicinal Chemistry, 19(1), 35-42.

Tarasenko, L. M., Neporada, K. S., Skrypnik, I. N., \& Volozhin, A. I. (2001). Jeksperimental'naja model' pepticheskoj jazvy zheludka [Experimental model of peptic ulcer of the stomach]. Patologicheskaja Fiziologija i Jeksperimental'naja Medicina, 1, 27-28 (in Russian).

Tarnawski, A. S., Ahluwalia, A., \& Jones, M. K. (2012). The mechanisms of gastric mucosal injury: Focus on microvascular endothelium as a key target. Current Medicinal Chemistry, 19(1), 4-15.

Tkach, S. M., Puchkov, K. S., \& Kuzenko, Y. G. (2013). Biologicheskiye effekty oksidov azota $\mathrm{v}$ zheludochno kishechnom trakte [Biological effects of nitric oxide in the gastrointestinal tract]. Suchasna Gastroyenterologíya, 72(4), 118-128 (in Russian). van Zwieten, R., Verhoeven, A. J., \& Roos, D. (2014). Inborn defects in the antioxidant systems of human red blood cells. Free Radical Biology and Medicine, 67(2), 377-386

Wallace, J. L., Ianaro, A., \& de Nucci, G. (2017). Gaseous mediators in gastrointestinal mucosal defense and injury. Digestive Diseases and Sciences, 62(9), 2223-2230.

Wu, G. (1998). Intestinal mucosal amino acid catabolism. Jomal of Nutrition, 128(8), 1249-1252

Yandrapu, H., \& Sarosiek, J. (2015). Protective factors of the gastric and duodenal mucosa: An overview. Current Gastroenterology Reports, 17(6), 24.

Yermishev, O., Lykholat, T., \& Lykholat, O. (2017). Effect of alimentary synthetic estrogen on cell compensatory mechanisms in rats of different ages. Biologia, 63(2), 152-159.

Zolotarev, V. A., Andreeva, Y. V., Vershinina, E., \& Khropycheva, R. P. (2017). Interaction of constitutive nitric oxide synthases with cyclooxygenases in regulation of bicarbonate secretion in the gastric mucosa. Bulletin of Experimental Biology and Medicine, 163(1), 6-9.

Zolotova, N. A. (2014). Strukturnaya i funktsional'naya kharakteristika mutsinov [Structural and functional characteristics of mucins]. Klinicheskaya i funktsional'naya Morfologiya, 1, 66-72 (in Russian). 